\title{
Enhancing the reversible capacity and cycle stability of lithium-ion batteries with Li-compensation material $\mathrm{Li}_{6} \mathrm{CoO}_{4}$
}

\author{
Ziyu Na ${ }^{1}$, Chao Lai ${ }^{2}$, Jiang Zhou ${ }^{3}$, Hongzhou Zhang ${ }^{1 *}$, Dawei Song ${ }^{1}$, Xixi Shi ${ }^{1}$ and Lianqi Zhang ${ }^{{ }^{*}}$
}

\begin{abstract}
High-capacity anode materials, such as $\mathrm{SiO}$ and $\mathrm{Si} / \mathrm{C}$, are considered promising candidates for high-energydensity lithium-ion batteries. However, the low initial Coulombic efficiency of these anode materials induced by side reactions (forming $\mathrm{Li}_{2} \mathrm{O}$ and lithium silicate) and the formation of solid electrolyte interface film reduces the active Liions and causes low-discharge capacity. Adding a Li-compensation material in the cathode or anode is an effective strategy to overcome this problem. The most used Li-compensation material is the stabilized lithium metal powder. However, this strategy has high safety risks, high costs, and is challenging to quantify. Herein, the Li-compensation material of $\mathrm{Li}_{6} \mathrm{CoO}_{4}$ is synthesized and investigated. The preparation conditions, stability in the air, delithiation mechanism, and structural transformation are analyzed and discussed. Electrochemical tests reveal that the discharge capacity and capacity retention of the full pouch cells (3-Ah) with $\mathrm{Li}_{6} \mathrm{CoO}_{4}$ additive is significantly improved. Also, the reason for such improvement is investigated. This work provides an effective strategy of Li-compensating technology to enhance the electrochemical performance of lithium-ion batteries.
\end{abstract}

Keywords: lithium-ion batteries, Li-compensation, $\mathrm{Li}_{6} \mathrm{CoO}_{4}$, Coulombic efficiency, cycle performance

\section{INTRODUCTION}

With the rapid development of applications, such as portable electronic devices and electric vehicles, lithium-ion batteries with high energy density are urgently needed [1-5]. As a conventional anode material, graphite is used in commercial lithium-ion batteries. However, the theoretical specific capacity of graphite is low $\left(372 \mathrm{~mA} \mathrm{~h}^{-1}\right)$, which cannot meet the increasing demand for high energy density [6-8]. Meanwhile, silicon anode possesses a theoretical capacity of $4200 \mathrm{~mA} \mathrm{~h} \mathrm{~g}^{-1}$, which is ten times larger than that of graphite [9-11]. Nevertheless, the huge volume change $(>300 \%)$ during the chargedischarge process significantly decreases the efficiency and capacity of the batteries $[12-14] . \mathrm{SiO}_{x}(0<x<2)$ anode material can generate $\mathrm{Li}_{2} \mathrm{O}$ and lithium silicate during the first cycle, which can accommodate the volume change and inhibit particle agglomeration [15-17]. Therefore, the Coulombic efficiency and cycle stability of $\mathrm{SiO}_{x}$ can be significantly improved. However, the formation of $\mathrm{Li}_{2} \mathrm{O}$ and lithium silicate consumes a large amount of Li-ions, significantly decreasing the Coulombic efficiency and discharge capacity of lithium-ion batteries [18-21]. Li-compensation is an effective method to solve this problem and has become a research hotspot recently.

Stabilized lithium metal powder (SLMP) is the most direct way to compensate lithium for lithium-ion batteries [22-28]. However, this method suffers from several disadvantages. (1) High environmental requirements. Li powder has high activity and poor stability in the air. Even for SLMP, dry air is needed. (2) Safety issues: fine powder can cause an explosion in the air, which is very dangerous for the highly reactive lithium powder. (3) Incompatibility with the existing production processes of lithium-ion batteries. Additional equipment and procedures are required to compensate for lithium with SLMP, which considerably affects the existing lithium-ion battery production process. (4) High cost: solving the above problems brings high costs. (5) Hard to quantify accurately: the amount of Li-compensation material needs to be accurately quantified. Minute lithium compensation has no effect, whereas excess quantity causes the growth of lithium dendrite, inducing safety hazards. Excessive lithium replenishment is likely to occur using the SLMP. Therefore, it is urgently needed to develop new Licompensation materials with high Li-compensation capacity, high safety, and low cost.

Recently, antifluorite $\mathrm{Li}_{5} \mathrm{FeO}_{4}, \mathrm{Li}_{4} \mathrm{CoO}_{4}$, and $\mathrm{Li}_{5} \mathrm{ReO}_{6}$ are considered promising Li-compensation materials owing to their high capacity, high security, and low cost. Nevertheless, only a few studies exist on these materials. Lu and co-workers $[29,30]$ investigated the $\mathrm{Li}$-compensation effect of $\mathrm{Li}_{5} \mathrm{FeO}_{4}$. The synthesized $\mathrm{Li}_{5} \mathrm{FeO}_{4}$ was added to the $\mathrm{LiNi}_{0.5} \mathrm{Co}_{0.2} \mathrm{Mn}_{0.3} \mathrm{O}_{2}$ (NCM523) electrode with a weight ratio of NCM523: $\mathrm{Li}_{5} \mathrm{FeO}_{4}=$ 10:1. SiO was used as the anode material. The initial discharge capacity of the full battery with $\mathrm{Li}_{5} \mathrm{FeO}_{4}$ was $140.8 \mathrm{~mA} \mathrm{~h} \mathrm{~g}^{-1}$, which exceeded that of the cell without $\mathrm{Li}_{5} \mathrm{FeO}_{4}\left(126.8 \mathrm{~mA} \mathrm{~h} \mathrm{~g}^{-1}\right)$. Jeżowski et al. [31] found that $\mathrm{Li}_{5} \mathrm{ReO}_{6}$ can be used as a $\mathrm{Li}$ compensation material for lithium-ion capacitors. A Li-compensation capacity of $410 \mathrm{~mA} \mathrm{hg}^{-1}$ was obtained at $2.5-4.3 \mathrm{~V}$. Energy and power density values of $40 \mathrm{~W} \mathrm{~h} \mathrm{~kg}^{-1}$ and $0.5 \mathrm{~kW} \mathrm{~kg}^{-1}$, respectively, were obtained. Furthermore, $\mathrm{Li}_{6} \mathrm{CoO}_{4}$ has a high theoretical capacity $\left(977.1 \mathrm{~mA} \mathrm{hg}^{-1}\right)$ and high irreversibility, which is believed to be a promising Li-compensation material. The charge and discharge capacities of $\mathrm{Li}_{6} \mathrm{CoO}_{4}$ prepared by

\footnotetext{
${ }^{1}$ Tianjin Key Laboratory for Photoelectric Materials and Devices, School of Materials Science and Engineering, Tianjin University of Technology, Tianjin 300384, China

${ }^{2}$ School of Chemistry and Materials, Jiangsu Normal University, Xuzhou 221116, China

${ }^{3}$ Tianjin Lishen Battery Joint-stock Co. Ltd., Huayuan Science \& Technology Park, Tianjin 300074, China

* Corresponding authors (emails: zhanghongzhou@mail.nankai.edu.cn (Zhang H); tianjinzhanglq@163.com (Zhang L))
} 
Noh et al. [32] were 318 and $13 \mathrm{~mA} \mathrm{~h} \mathrm{~g}^{-1}$, respectively, at $4.7 \mathrm{~V}$. Besides, $\mathrm{Li}_{6} \mathrm{CoO}_{4}(15 \mathrm{wt} \%)$ was added to the $\mathrm{LiCoO}_{2}$ electrode and assembled with a silicon-based anode. The first discharge capacity with the $\mathrm{Li}_{6} \mathrm{CoO}_{4}$ material was $133 \mathrm{~mA} \mathrm{~h} \mathrm{~g}^{-1}$, whereas that of the cell without $\mathrm{Li}_{6} \mathrm{CoO}_{4}$ was only $77 \mathrm{mAhg}^{-1}$. Additionally, the electrochemical performance of the Li-ion capacitor with the $\mathrm{Li}_{6} \mathrm{CoO}_{4}$ additive was investigated [33]. Herein, the preparation condition, the stability in the air, the delithiation mechanism, and the structural transformation of $\mathrm{Li}_{6} \mathrm{CoO}_{4}$ are analyzed and discussed. Furthermore, to examine the Li-compensating effect of $\mathrm{Li}_{6} \mathrm{CoO}_{4}$, full pouch cells (3-Ah) are assembled, and the electrochemical performances are investigated.

\section{EXPERIMENTAL SECTION}

\section{Material preparation}

$\mathrm{Li}_{6} \mathrm{CoO}_{4}$ was synthesized by the high-temperature solid-phase method. $\mathrm{CoO}$ and $\mathrm{LiOH}$ (excess molar ratio 5\%) were carefully ground in a corundum crucible and then sintered at 650, 700, 750 , or $800^{\circ} \mathrm{C}$ for $20 \mathrm{~h}$ under nitrogen atmosphere. The as-prepared $\mathrm{Li}_{6} \mathrm{CoO}_{4}$ was ground and stored in a glove box filled with argon to prevent it from reacting with $\mathrm{H}_{2} \mathrm{O}$ and $\mathrm{CO}_{2}$. $\mathrm{LiNi}_{0.70} \mathrm{Co}_{0.10} \mathrm{Mn}_{0.20} \mathrm{O}_{2}$ (referred to as NCM) cathode material was prepared by combining the coprecipitation and high-temperature solid-phase methods, similar to our previous work [34]. Hard carbon (HC) and $\mathrm{Si} / \mathrm{C}$ composite anode materials were commercially available.

\section{Materials characterization}

The crystal structure and composition of the composite electrode materials were determined using an X-ray powder diffractometer (D/Max-2500, Rigaku, Cu Ka radiation). A highresolution transmission electron microscope (HRTEM, Talos F200 X) was used to confirm the micromorphology and microstructure of the prepared materials. The surface morphologies of the $\mathrm{Li}_{6} \mathrm{CoO}_{4}$ materials sintered at different temperatures were characterized using a field emission scanning electron microscope (FESEM, Quantum FEG 250). An ex situ Xray diffractometer (XRD, Rigaku Ultima IV) was used to analyze the structural changes of $\mathrm{Li}_{6} \mathrm{CoO}_{4}$ during the first cycle. The valence state of the elements in the $\mathrm{Li}_{6} \mathrm{CoO}_{4}$ electrode during the first cycle was identified using X-ray photoelectron spectroscopy (XPS, Escalab250Xi). For ex situ XPS and XRD analyses, batteries were carefully disassembled in a glove box, and the collected electrodes were washed with glycol dimethyl ether to remove residual electrolyte.

\section{Electrode preparation and cell assembly}

First, the prepared active materials, acetylene black, and polyvinylidene fluoride (PVDF) (weight ratio of 8:1:1) were mixed in $\mathrm{N}$-methyl pyrrolidone to form a homogeneous slurry, which was coated on an $\mathrm{Al}$ foil and dried at $120^{\circ} \mathrm{C}$ for $10 \mathrm{~h}$. Next, it was dried for $10 \mathrm{~h}$ under a vacuum. Finally, roll-pressing was performed, and the electrodes were cut into 12-mm-diameter wafers to assemble CR2032 coin cells. The dried electrodes, lithium plate, and Celgard 2400 microporous membrane were used as the cathode, anode, and separator, respectively. $\mathrm{LiPF}_{6}$ $\left(1 \mathrm{~mol} \mathrm{~L}^{-1}\right)$ was dissolved in a mixture of ethylene carbonate and diethyl carbonate (volume ratio $=1: 1$ ) to form the electrolyte. The NCM cathode and graphite (denoted by GR) anode were used to prepare a full pouch battery (3-Ah). The NCM electrode containing B was written as NCM + L6C. The full pouch battery without $\mathrm{Li}_{6} \mathrm{CoO}_{4}$ was recorded as $\mathrm{NCM}-\mathrm{GR}$, and the battery with $\mathrm{Li}_{6} \mathrm{CoO}_{4}$ was written as $(\mathrm{NCM}+\mathrm{L} 6 \mathrm{C})-\mathrm{GR}$. The mass ratio of $\mathrm{NCM}$ and $\mathrm{L}_{6} \mathrm{CoO}_{4}$ was 9:1 in the NCM + L6C electrode.

\section{RESULTS AND DISCUSSION}

When charging lithium-ion batteries, Li-ions are extracted from the cathode and migrate to the anode. In the following discharge process, when the $\mathrm{SiO}_{x}$ anode is employed, some $\mathrm{Li}$ ions lose their activity due to the formation of $\mathrm{Li}_{2} \mathrm{O}$, lithium silicate, and solid electrolyte interphase (SEI) film, resulting in low Coulombic efficiency of the battery. When $\mathrm{Li}_{6} \mathrm{CoO}_{4}$ is added, $\mathrm{Li}$ ions released from $\mathrm{Li}_{6} \mathrm{CoO}_{4}$ during the initial charging process can effectively compensate for the loss of lithium. Consequently, the reversible capacity of the battery is improved greatly. Fig. S1 presents the role of $\mathrm{Li}_{6} \mathrm{CoO}_{4}$ and the Li-compensation mechanism. To obtain $\mathrm{Li}_{6} \mathrm{CoO}_{4}$ with high specific capacity, the calcination temperature of $\mathrm{Li}_{6} \mathrm{CoO}_{4}$ is optimized. Fig. 1a shows the XRD patterns of $\mathrm{Li}_{6} \mathrm{CoO}_{4}$ materials synthesized at different temperatures. They are denoted as L6C-650, L6C-700, L6C750 , and $\mathrm{L} 6 \mathrm{C}-800$ according to their calcination temperatures. At a sintering temperature of $750^{\circ} \mathrm{C}$, the main diffraction peaks correspond well to $\mathrm{Li}_{6} \mathrm{CoO}_{4}$ (PDF\# 75-1819) with an antifluorite structure, which belongs to the $P 4_{2} / n m c$ space group (cell parameters $a=6.536 \AA$ and $b=4.654 \AA$ ).

Some impurities, such as $\mathrm{CoO}$ and $\mathrm{Co}_{2} \mathrm{O}_{3}$, can be observed at $36.8^{\circ}$ and $42.7^{\circ}$, especially for samples synthesized at 650,700 , and $800^{\circ} \mathrm{C}$. The diffraction peaks of $\mathrm{L} 6 \mathrm{C}-750$ are strong and sharp, indicating that the $\mathrm{Li}_{6} \mathrm{CoO}_{4}$ material prepared at $750^{\circ} \mathrm{C}$ has high crystallinity. Fig. $1 \mathrm{~b}-\mathrm{e}$ show the surface micromorphology of $\mathrm{Li}_{6} \mathrm{CoO}_{4}$ materials prepared at different temperatures; no significant surface morphology and grain size difference can be observed. The as-prepared samples exist in loose aggregates of the primary grains with $\sim 5 \mu \mathrm{m}$ diameter. It seems that the particles gradually agglomerate when the temperature increases to $800^{\circ} \mathrm{C}$, which may adversely affect the extraction of $\mathrm{Li}$ ions from the grains.

Fig. 2a shows the TEM images of $\mathrm{Li}_{6} \mathrm{CoO}_{4}$ synthesized at $750^{\circ} \mathrm{C}$. The particle size is $\sim 3 \mu \mathrm{m}$, which is similar to the SEM images (Fig. 1). Fig. 2b shows the lattice fringe of $\mathrm{Li}_{6} \mathrm{CoO}_{4}$. The uniform distribution of lattice stripes can be observed, which is consistent with the XRD results. The long arrow in Fig. 2c represents ten times the interplanar spacing of the (110) plane. The interplanar spacing is calculated to be $0.464 \mathrm{~nm}$, which is almost the same as the $0.463-\mathrm{nm}$ value of the (110) plane spacing of PDF\# 38-1140. Fig. 2d shows the corresponding fast Fourier transform (FFT). Clear and ordered electron diffraction patterns of the (110) plane can be found in the image, which illustrates the excellent crystallinity of the prepared $\mathrm{Li}_{6} \mathrm{CoO}_{4}$.

Fig. 2e shows the initial charge-discharge curves of the $\mathrm{Li}_{6} \mathrm{CoO}_{4}$ materials prepared at different calcination temperatures. As the temperature increases, the initial charge capacity of $\mathrm{Li}_{6} \mathrm{CoO}_{4}$ increases. However, when the temperature increases to $800^{\circ} \mathrm{C}$, the charge capacity of $\mathrm{Li}_{6} \mathrm{CoO}_{4}$ decreases significantly. This phenomenon may be due to the increase in impurities and the partially destroyed structure of $\mathrm{Li}_{6} \mathrm{CoO}_{4}$, which can be illustrated by the impurity peaks and the low diffraction intensity of L6C-800 in Fig. 1. An initial charge capacity of $573.6 \mathrm{~mA} \mathrm{~h} \mathrm{~g}^{-1}$ is obtained when $\mathrm{Li}_{6} \mathrm{CoO}_{4}$ is prepared at $750^{\circ} \mathrm{C}$. However, in the following discharge process, a low discharge capacity of only 

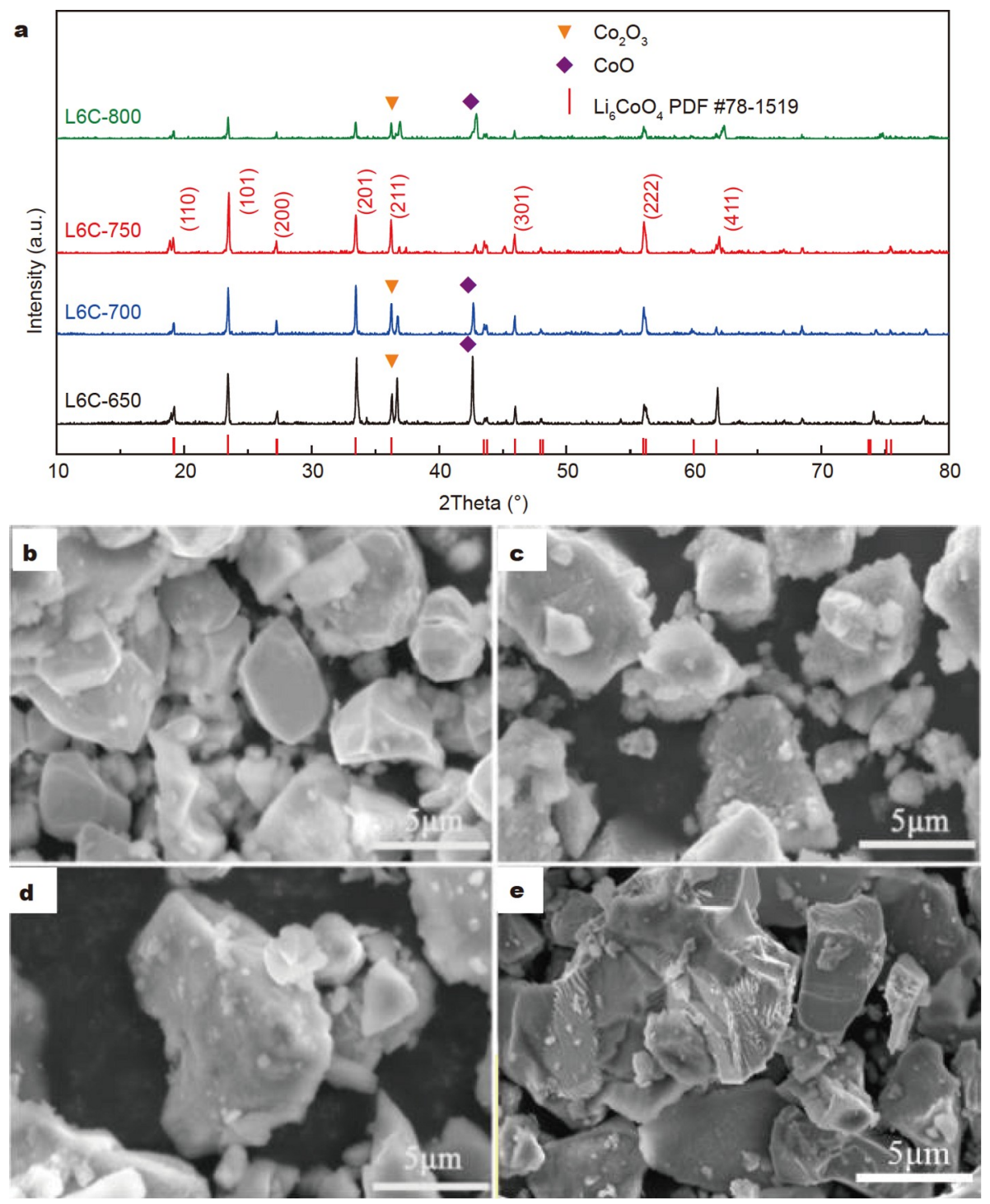

Figure 1 (a) $\mathrm{XRD}$ patterns of $\mathrm{Li}_{6} \mathrm{CoO}_{4}$ samples synthesized at various temperatures. $\mathrm{SEM}$ images of $\mathrm{Li}_{6} \mathrm{CoO}_{4}$ samples synthesized at (b) $650^{\circ} \mathrm{C}$, (c) $700^{\circ} \mathrm{C}$, (d) $750^{\circ} \mathrm{C}$, and (e) $800^{\circ} \mathrm{C}$.

$25.6 \mathrm{~mA} \mathrm{~h} \mathrm{~g}^{-1}$ is obtained, which may be attributed to the irreversible phase transition of antifluorite $\mathrm{Li}_{6} \mathrm{CoO}_{4}$ [9]. Due to the high charge and low discharge capacities of the $\mathrm{Li}_{6} \mathrm{CoO}_{4}$ electrode, a high Li-compensation capacity of $548 \mathrm{~mA} \mathrm{~h} \mathrm{~g}^{-1}$ (573.6 $-25.6 \mathrm{~mA} \mathrm{~h} \mathrm{~g}^{-1}$ ) can be obtained for L6C-750. Fig. S2 shows the initial $\mathrm{dQ} / \mathrm{d} V$ curves of the four $\mathrm{Li}_{6} \mathrm{CoO}_{4}$ samples prepared at various temperatures. Three oxidation peaks at $\sim 3.3,3.65$, and $3.95 \mathrm{~V}$ can be found in the anodic process. The peaks located at $3.3 \mathrm{~V}$ are related to the oxidation of $\mathrm{Co}^{2+} / \mathrm{Co}^{3+}$. Meanwhile, two oxidation peaks at $\sim 3.65$ and $3.95 \mathrm{~V}$ are caused by the oxidation reactions of $\mathrm{Co}^{3+} / \mathrm{Co}^{4+}$ and $\mathrm{O}^{2-} / \mathrm{O}_{2}^{(2-n)-}[13-16]$. The redox peak area in the cyclic voltammetry $(\mathrm{CV})$ curve represents the electrode's capacity. The area of the three oxidation peaks is large, illustrating a large Li-extraction capacity in the anodic process. However, in the following cathodic process, only a sharp reduction peak with a low area is present, which is in accordance with the low reversible capacity of the $\mathrm{Li}_{6} \mathrm{CoO}_{4}$ electrode.

It is expected that Li-compensation materials have good air stability. Herein, $\mathrm{Li}_{6} \mathrm{CoO}_{4}$ powder was exposed to air for dif- ferent durations $(1,10$, and 20 h; relative humidity $(\mathrm{RH})=50 \%)$ to examine its air stability. As shown in Fig. S3a-c, compared with the pristine $\mathrm{Li}_{6} \mathrm{CoO}_{4}$ material, the peak position and intensity remained almost unchanged after 1-h exposure. However, the impurity peaks at $31^{\circ}$ and $32^{\circ}$, which correspond to the diffraction peak of $\mathrm{Co}_{3} \mathrm{O}_{4}$, become stronger as the exposure time increases. Besides, many other impurity peaks can be observed, such as those at $21^{\circ}$ and $37^{\circ}$. The surface micromorphologies of $\mathrm{Li}_{6} \mathrm{CoO}_{4}$ exposed for different durations are shown in Fig. S4a-d. The particle size and morphology remained unchanged after 1-h exposure. However, the small particles aggregate into large elliptical particles after exposure for more than $10 \mathrm{~h}$. The initial charge-discharge performance of $\mathrm{Li}_{6} \mathrm{CoO}_{4}$ after exposure for different durations is shown in Fig. S5. The irreversible capacity of $\mathrm{Li}_{6} \mathrm{CoO}_{4}$ exposed for $1 \mathrm{~h}$ in the air $(50 \%$ $\mathrm{RH}$ ) is slightly less than that of the fresh one, whereas the irreversible capacities of samples after 10 and $20 \mathrm{~h}$ are considerably less than that of the fresh one. Based on the above analysis, it can be inferred that the short-term contact with air 

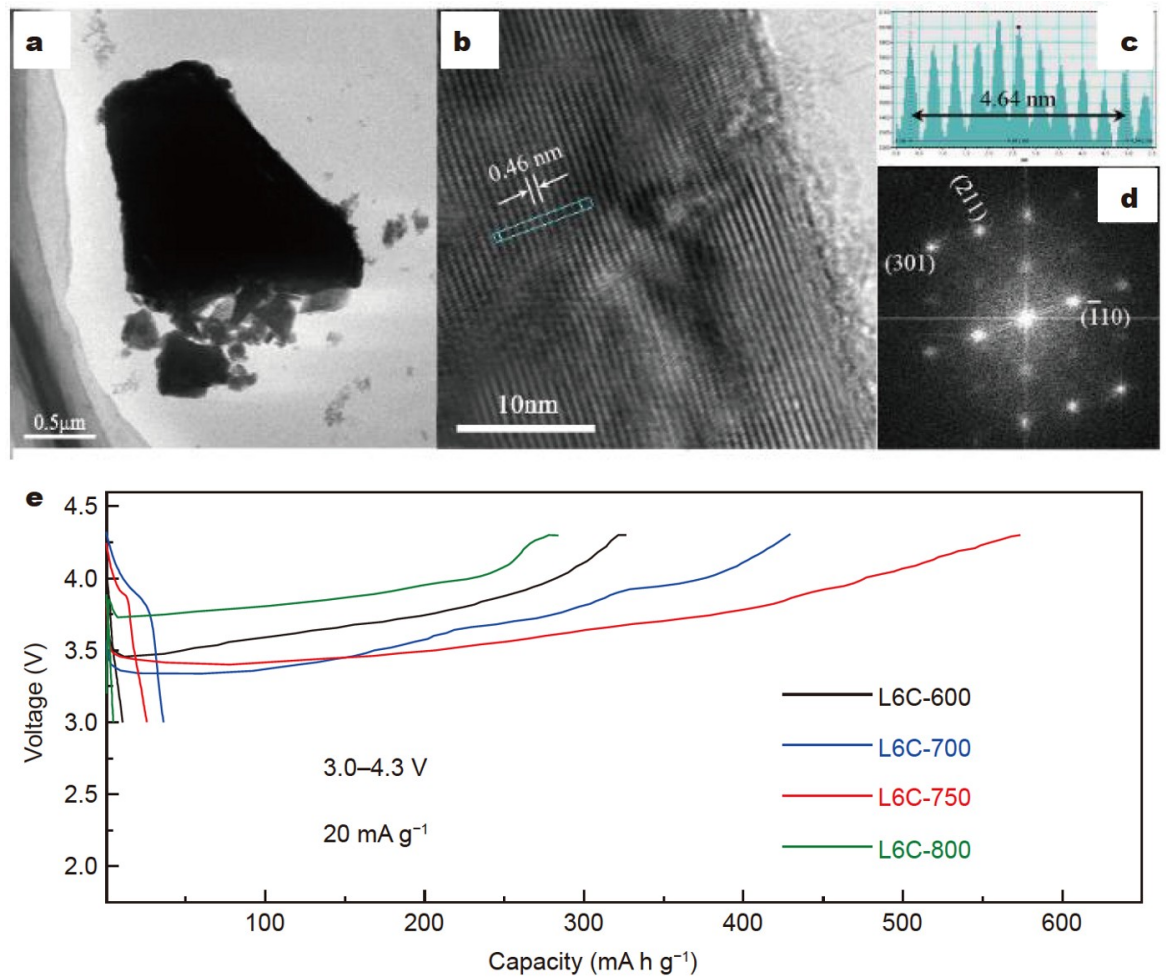

Figure 2 (a) TEM and (b) HRTEM images of $\mathrm{Li}_{6} \mathrm{CoO}_{4}$. (c) displays ten times of the (110) interplanar spacing. (d) FFT images of (b). (e) Initial charge and discharge curves of $\mathrm{Li}_{6} \mathrm{CoO}_{4}$ at different sintering temperatures.

(within $1 \mathrm{~h}$ ) will not significantly affect the structure, morphology, and properties of $\mathrm{Li}_{6} \mathrm{CoO}_{4}$, indicating much better air stability of $\mathrm{Li}_{6} \mathrm{CoO}_{4}$ than that of SLMP (cannot be stored under such high humidity conditions (50 RH\%)). However, after a long time of contact with moisture, oxygen, and carbon dioxide in the air, $\mathrm{Co}^{2+}$ may be oxidized to $\mathrm{Co}^{3+}$ and some impurities appear. It can be inferred that the electrochemical performance of the $\mathrm{Li}_{6} \mathrm{CoO}_{4}$ samples will deteriorate with more than $10 \mathrm{~h}$ of exposure time.

Ex situ XPS was conducted to examine the chemical states of $\mathrm{Co}$ and $\mathrm{O}$ during the first charge (delithiation) process of the $\mathrm{Li}_{6} \mathrm{CoO}_{4}$ (L6C-750) material (Fig. 3). Fig. 3a shows the initial charge curve of the electrode, and the core-level spectra of Co $2 \mathrm{p}_{3 / 2}$ and $\mathrm{O} 1 \mathrm{~s}$ at various states of charge of the electrode (Fig. 3a) are analyzed and listed in Fig. 3b, c. For the fresh $\mathrm{Li}_{6} \mathrm{CoO}_{4}$ material, a peak at $779.9 \mathrm{eV}$ can be found, corresponding to $\mathrm{Co}^{2+}$ in $\mathrm{Li}_{6} \mathrm{CoO}_{4}$. For the $\mathrm{Li}_{6-x} \mathrm{CoO}_{4}$ samples, the peak value of Co $2 \mathrm{p}_{3 / 2}$ shifts gradually to higher binding energy, indicating an increment in the oxidation state of Co along with an increase in the $x$ value. When $x=1.0\left(1-\mathrm{mol} \mathrm{Li}^{+}\right.$extracted from $\mathrm{Li}_{6} \mathrm{CoO}_{4}$ ), the peak value of $\mathrm{Co}$ is located at $780.5 \mathrm{eV}$, which is assigned to $\mathrm{Co}^{3+}$ [35]. As more $\mathrm{Li}$ ions are extracted and $x$ increases, the peak at $781.5 \mathrm{eV}$ becomes more obvious, which is attributed to $\mathrm{Co}^{4+}$. Also, Fig. $3 \mathrm{c}$ examines the $\mathrm{O} 1 \mathrm{~s}$ spectra during the first charge. When $x \leq 2$, the peak positions and intensities of $\mathrm{O} 1 \mathrm{~s}$ are almost the same, implying that the chemical states of $\mathrm{O}$ remain unchanged. When $x>2$, the $\mathrm{O} 1$ s peak located at 531.9$532.7 \mathrm{eV}$ can be observed, corresponding to $\mathrm{O}_{2}{ }^{(2-n)^{-}}$species $[36,37]$. The existence of $\mathrm{O}_{2}{ }^{(2-n)^{-}}$species implies that the $\mathrm{O}^{2-} / \mathrm{O}_{2}{ }^{(2-n)-}$ oxidation process occurs when $x>2$ in the charging process. The peak value of $\mathrm{O} 1 \mathrm{~s}$ gradually shifts to higher binding energy, and the peak area enlarges when $x>2$, implying that more $\mathrm{O}^{2-}$ is oxidized to $\mathrm{O}_{2}^{(2-n)-}$, which contributes to a high capacity in the charging process [38].

To illustrate the structural evolution of $\mathrm{Li}_{6-x} \mathrm{CoO}_{4}$ during the charging process, ex situ XRD patterns of the $\mathrm{Li}_{6} \mathrm{CoO}_{4}$ electrodes at different charging states were collected (Fig. 4), and the contour plot (Fig. 4a) is drawn to illustrate the process of structural change clearly. The color depth in the contour plot represents the diffraction intensity. When $x<1.0$, the intensity of the (101) peak gradually weakens as $x$ increases (Fig. 4b, c). When $x>1$, the color in the contour plot of the (201) peak becomes lighter, implying that the diffraction intensity of the (201) peak weakens. Besides, a new diffraction peak appears at $\sim 18.6^{\circ}$, which can be attributed to the Miller indices (111) of $\mathrm{Co}_{3} \mathrm{O}_{4}$. Also, the color of this new peak in the contour plot gradually turns red, and its intensity gradually increases as $x$ increases, illustrating that more $\mathrm{Co}^{3+}$ is produced. This distinctive feature of the structural evolution is attributed to the deep delithiation process of $\mathrm{Li}_{6} \mathrm{CoO}_{4}$ at high voltages, according to the XPS analysis and the high discharge capacity referred above.

According to the above structural evolution analysis of $\mathrm{Li}_{6} \mathrm{CoO}_{4}$ during the initial charge process, the Li-compensation mechanism of $\mathrm{Li}_{6} \mathrm{CoO}_{4}$ during the charging process can be summarized as Equations (1) and (2). The removal of Li ions is accompanied by the oxidation of $\mathrm{Co}^{2+}$ in the first stage (Equation (1)). Co can only be oxidized to $\sim+3.6$ (the mixing of $\mathrm{Co}^{3+/ 4+}$ ) before the oxygen loss begins due to an overlap of the $\mathrm{Co}^{3+/ 4+}: t_{2 \mathrm{~g}}$ band with the top of the $\mathrm{O}^{2-}: 2 \mathrm{p}$ band [39], which corresponds to the charging capacity of $261 \mathrm{~mA} \mathrm{~h} \mathrm{~g}^{-1}$ with $1.6-$ mol $\mathrm{Li}$ ions removed. When more $\mathrm{Li}$ ions are removed, the 

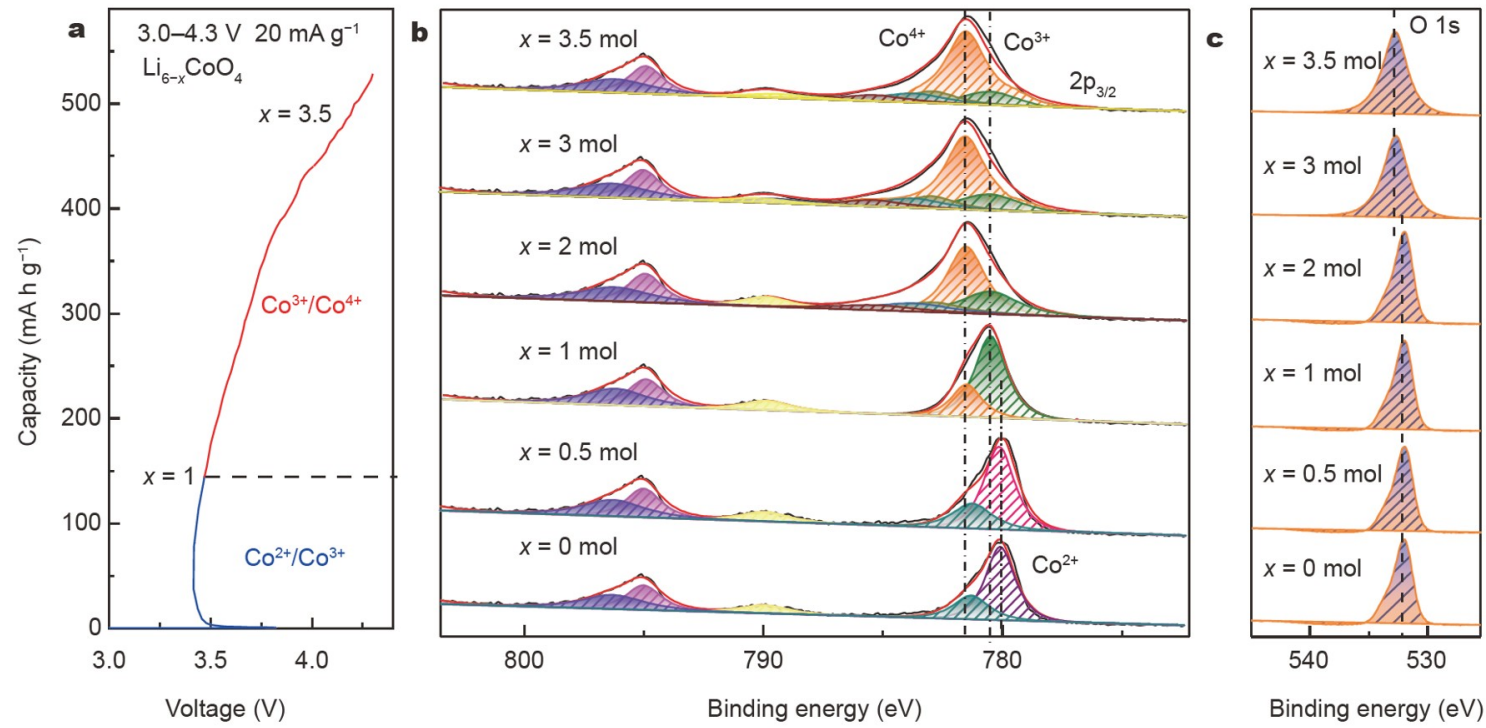

Figure 3 (a) Charge (delithiation) profiles of $\mathrm{Li}_{6-x} \mathrm{CoO}_{4}$ between 3.0 and $4.3 \mathrm{~V}$ with a current density of $0.1 \mathrm{C}(1 \mathrm{C}=200 \mathrm{~mA} \mathrm{~g}$ ). XPS of (b) Co $2 \mathrm{p}$ and (c) $\mathrm{O} 1 \mathrm{~s}$ at different charge states.

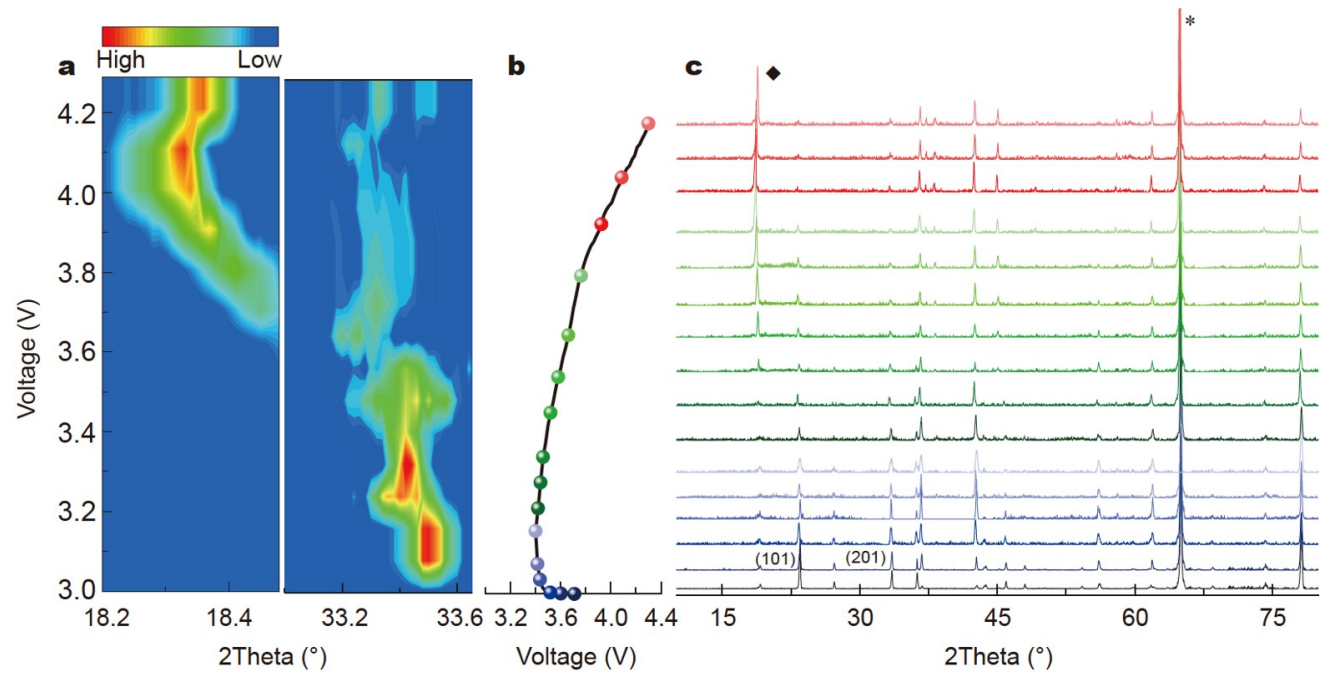

Figure 4 Ex situ XRD analysis of $\mathrm{Li}_{6-x} \mathrm{CoO}_{4}$ during the first charge. (a) Contour plot of XRD patterns in the ranges of $18.2^{\circ}-18.5^{\circ}$ and $33.1^{\circ}-33.7^{\circ}$. Based on different phase-transition processes, the different charging stages are distinguished by white dashed lines. (b) Charging curve of $\mathrm{Li}_{6-x} \mathrm{CoO}_{4}$ between 3.0 and $4.3 \mathrm{~V}$, with a current density of $0.1 \mathrm{C}\left(1 \mathrm{C}=200 \mathrm{~mA} \mathrm{~g}^{-1}\right)$. (c) Ex situ XRD patterns corresponding to various charge states. The dots in the charge curve correspond with the XRD spectra in sequence. The * and symbols in the XRD patterns refer to the diffraction peak of the Al current collector and the (111) peak of the $\mathrm{Co}_{3} \mathrm{O}_{4}$, respectively.

oxidation of $\mathrm{Co}^{4+}$ stops, and the charge compensation at this stage is mainly provided by the oxidation of $\mathrm{O}^{2-}$, as discussed in Fig. 3 and shown in Equation (2) (where $y=(2-m / 2) \times(2+n)$ according to the charge balance in the redox reactions).

$\mathrm{Li}_{6} \mathrm{CoO}_{4} \rightarrow \mathrm{Li}_{6-x} \mathrm{CoO}_{4}+x \mathrm{Li}^{+}+x \mathrm{e}^{-}(x \leq 2)$,

$\mathrm{Li}_{6-x} \mathrm{CoO}_{4} \rightarrow \mathrm{Li}_{6-x-y} \mathrm{CoO}_{m}+y \mathrm{Li}^{+}+y \mathrm{e}^{-}$

$+(2-m / 2) \mathrm{O}_{2}^{(2-n)-}(x>2)$.

The morphology and structure of the $\mathrm{Li}_{6} \mathrm{CoO}_{4}$ material in the NCM electrode were investigated via XRD and SEM. As shown in Fig. 5a, the characteristic diffraction peaks of NCM and $\mathrm{Li}_{6} \mathrm{CoO}_{4}$ materials can be observed, implying that $\mathrm{Li}_{6} \mathrm{CoO}_{4}$ exists in the cathode steadily. The micromorphologies of the NCM and
$\mathrm{NCM}+$ L6C electrodes are displayed in Fig. 5b, c, respectively. It can be observed that $\mathrm{Li}_{6} \mathrm{CoO}_{4}$ and $\mathrm{NCM}$ are dispersed uniformly.

Furthermore, the electrochemical performances of the NCM and NCM + L6C electrodes in half-cells were investigated (Fig. 6). Fig. 6a shows the initial charge-discharge curves. The first charge capacity of the NCM electrode is $215 \mathrm{~mA} \mathrm{~h} \mathrm{~g}^{-1}$, with a Coulombic efficiency of $90.3 \%$, whereas the first charge capacity of the NCM + L6C composite increases to $272.3 \mathrm{~mA} \mathrm{~h} \mathrm{~g}^{-1}$, with a Coulombic efficiency of $72.8 \%$. The low Coulombic efficiency of the NCM + L6C electrode is mainly due to the large compensation (irreversible) capacity of $\mathrm{Li}_{6} \mathrm{CoO}_{4}$. However, as the electrode's capacity is investigated in a half-cell, which can provide a sufficient amount of $\mathrm{Li}$ ions in the anode ( $\mathrm{Li}$ 

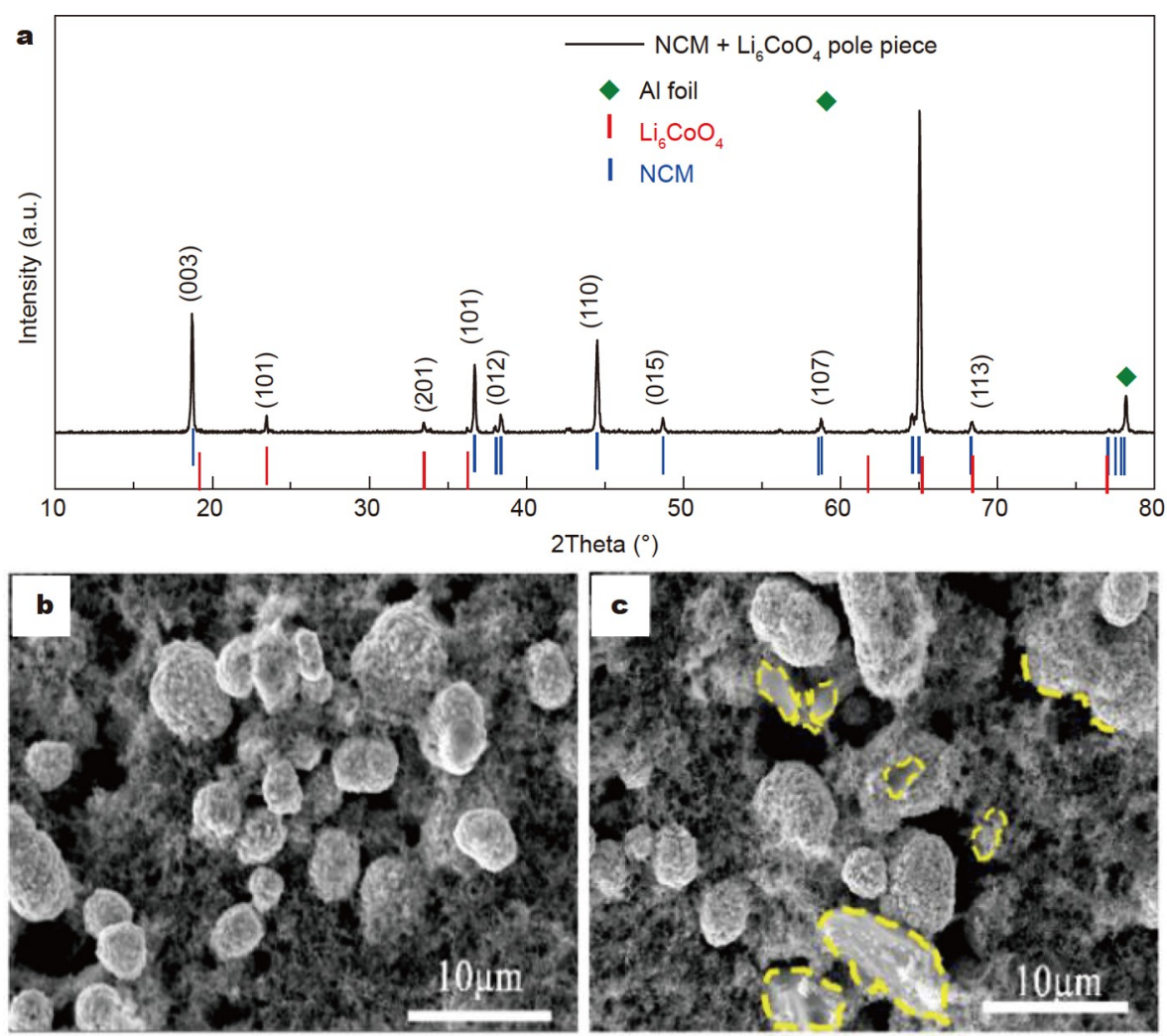

Figure 5 (a) XRD pattern of the NCM + L6C electrode. SEM images of the (b) NCM and (c) NCM + L6C electrodes.
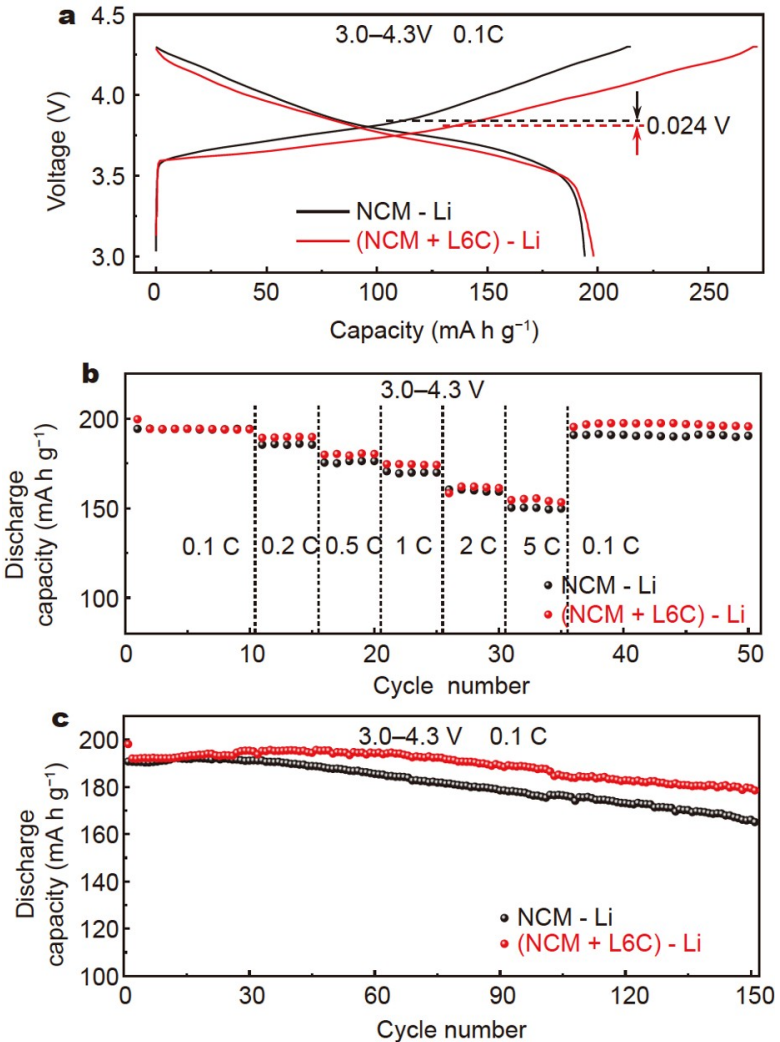

Figure 6 (a) Initial charge-discharge curves, (b) rate performances, and (c) cycle performances of NCM and NCM + L6C composite electrodes. $1 \mathrm{C}=$ $200 \mathrm{mAg}^{-1}$. metal), the difference between the discharge capacities of the two electrodes is small (194.1 and $198.1 \mathrm{~mA} \mathrm{~h} \mathrm{~g}^{-1}$ for the NCM and $\mathrm{NCM}+$ L6C electrodes, respectively). Besides, as shown in Fig. 6a, the average charge voltage of the NCM + L6C electrode is $3.811 \mathrm{~V}$, which is larger than that of the NCM electrode $(3.835 \mathrm{~V})$ and indicates a much lower polarization during the charge-discharge process. To reveal the reason for the low polarization of the NCM + L6C electrode, XRD patterns of the cycled $\mathrm{Li}_{6} \mathrm{CoO}_{4}$ electrode were examined (Fig. S6). Compared with the pristine material, the characteristic peak of $\mathrm{Li}_{6} \mathrm{CoO}_{4}$ disappears after the first cycle, and other cobalt oxide peaks can be found. The existence of cobalt oxide enhances the ionic and electronic conductivities of the electrode and thus decreases the polarization of the electrode, which may be responsible for the elevated discharge capacity of the NCM + L6C electrode. Moreover, lower polarization of the electrode increases the rate capabilities and capacity retention. Fig. $6 \mathrm{~b}$ shows the rate performances of the NCM and NCM + L6C electrodes. The rate performance of the NCM + L6C electrode is better than those of the pristine electrode. Fig. $6 \mathrm{c}$ displays the cycle performances of the two electrodes. Interestingly, after 150 cycles, the capacity retention of NCM and NCM + L6C electrodes is $86.6 \%$ and $93.0 \%$, respectively. The superior cycle capacity retention of the $\mathrm{NCM}+$ L6C electrode is mainly due to the low ohmic polarization, as discussed above.

The full pouch cells (3-Ah) were assembled to examine the Licompensation effect and the electrochemical performance of the $\mathrm{NCM}+$ L6C electrode (Fig. S7). The anode material of the full pouch cell is graphite (GR). Fig. 7 displays the initial chargedischarge curves and the cycle performances of the full battery. 
Fig. 7a shows that the initial charge and discharge capacities of the $(\mathrm{NCM}+\mathrm{L} 6 \mathrm{C})-\mathrm{GR}$ battery are 243.3 and $186.6 \mathrm{~mA} \mathrm{~h}^{-1}$, whereas those of the NCM-GR battery are 204.4 and $179.9 \mathrm{~mA} \mathrm{~h} \mathrm{~g}^{-1}$, respectively. The Coulombic efficiency of the $(\mathrm{NCM}+\mathrm{L} 6 \mathrm{C})-\mathrm{GR}$ battery is $76.7 \%$, which is lower than that of the NCM-GR battery (88.0\%); this is similar to Fig. 6a due to the compensation (irreversible) capacity of $\mathrm{Li}_{6} \mathrm{CoO}_{4}$. The higher discharge capacity and lower Coulombic efficiency of the (NCM + L6C)-GR battery confirm the Li-compensation effect of $\mathrm{Li}_{6} \mathrm{CoO}_{4}$ in the full battery.

Moreover, similar to Fig. 6a, the lower ohmic polarization is present in the first cycle of the (NCM + L6C)-GR battery (Fig. 7a), which is conducive to improving its cycle stability. The lower ohmic polarization of the (NCM + L6C)-GR battery can also be clearly illustrated by the average voltage during the cycle (Fig. 7c). The average charge voltage of the (NCM + L6C)-GR battery during the cycle is greater than that of $\mathrm{NCM}-\mathrm{GR}$, whereas the average discharge voltage of (NCM + L6C)-GR exceeds that of NCM-GR. The low polarization of the NCM + L6C electrode implies that the Li-compensation material, $\mathrm{Li}_{6} \mathrm{CoO}_{4}$, can reduce the charge-discharge polarization during the cycle, according to Figs $6 a$ and $7 a$. The cycle performances of
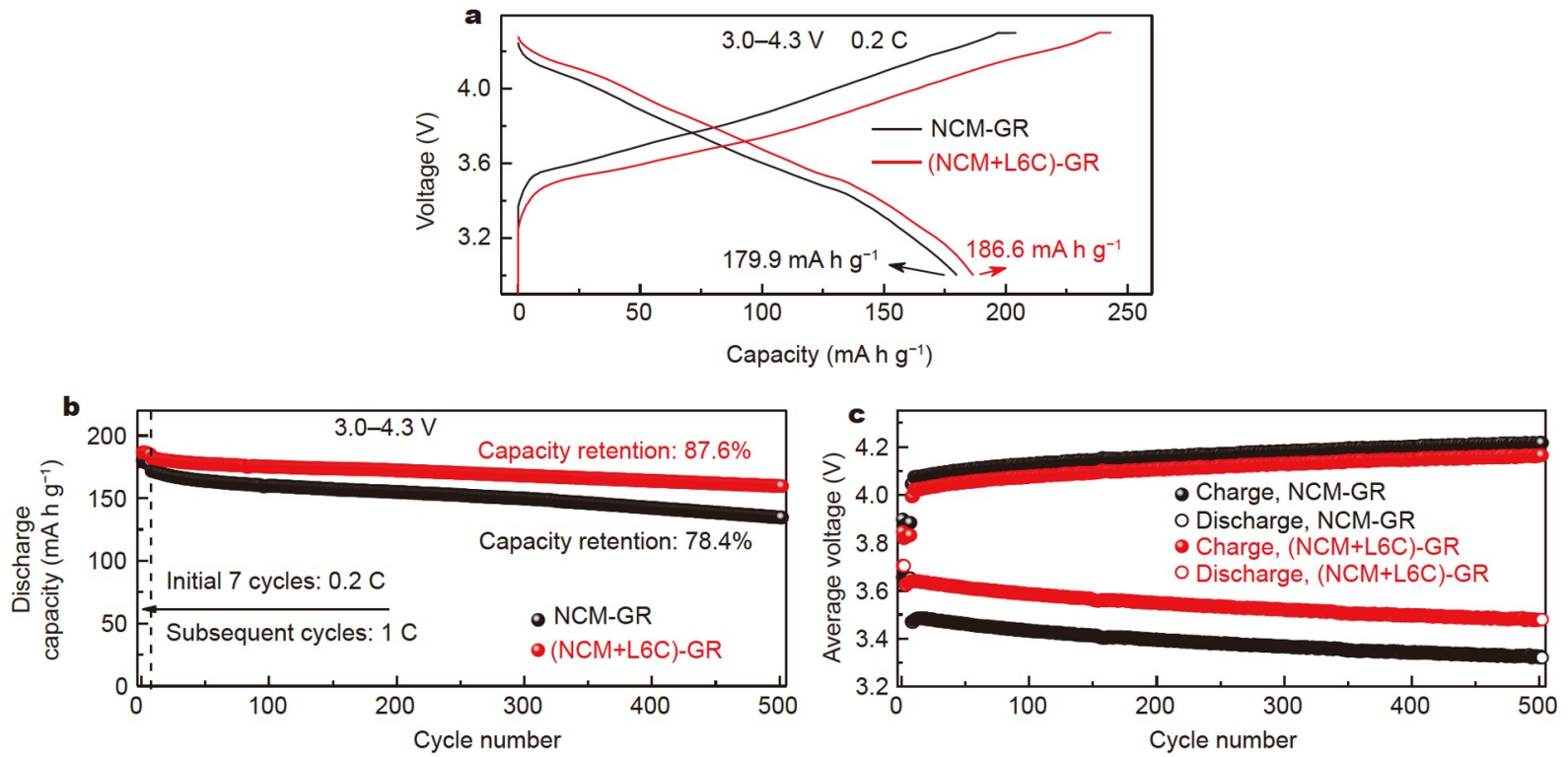

Figure 7 (a) Initial charge-discharge curves, (b) discharge capacities, and (c) average voltages versus cycle number of NCM-GR and (NCM + L6C)-GR full batteries. The open-circuit voltage of the full battery before the initial charge is 0 . The current density at $1 \mathrm{C}$ is $200 \mathrm{~mA} \mathrm{~g}^{-1}$. The average voltage is calculated based on the energy $\left(\mathrm{Wh} \mathrm{kg}^{-1}\right)$ and capacity $\left(\mathrm{mA} \mathrm{h} \mathrm{g}^{-1}\right)$.
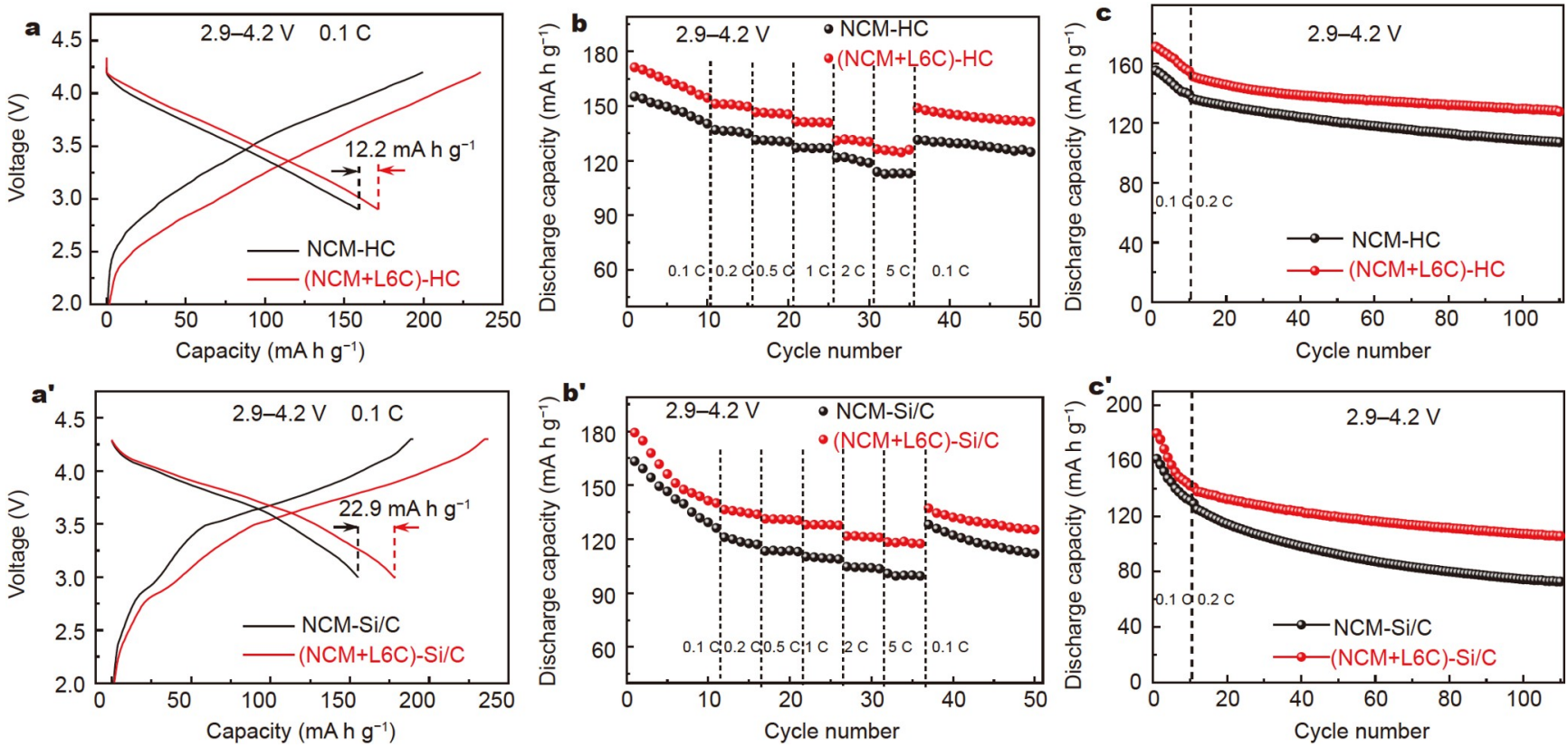

Figure 8 (a, a') First charge and discharge performance, (b, b') rate performance, and (c, c') cycle performance of CR2032 full cells. The open-circuit voltage of the fresh full cell is $0 \mathrm{~V}$, and the current density at $1 \mathrm{C}$ is $200 \mathrm{~mA} \mathrm{~g}^{-1}$. 
the two batteries are displayed in Fig. 7b. As expected, the capacity retention of the (NCM + L6C)-GR battery after 493 cycles at $1 \mathrm{C}$ is $85.7 \%$, which exceeds that of the NCM-GR battery $(75.3 \%)$, implying the improved cycle performance of the full pouch cells. The improved cycle stability of the (NCM + L6C)-GR battery is mainly due to the high ionic and electronic conductivity of the reaction product of $\mathrm{Li}_{6} \mathrm{CoO}_{4}$, as discussed above.

Fig. S8 shows the initial charge-discharge curves of the HC and $\mathrm{Si} / \mathrm{C}$ composite in the half coin cell. The initial charge capacity of $\mathrm{HC}$ is $295.6 \mathrm{~mA} \mathrm{~h} \mathrm{~g}^{-1}$, with a Coulombic efficiency of $80.3 \%$. The reversible capacity of $\mathrm{Si} / \mathrm{C}$ for the initial cycle is $534.4 \mathrm{~mA} \mathrm{~h} \mathrm{~g}^{-1}$, with a Coulombic efficiency of $89.2 \%$. Fig. $8 \mathrm{a}-\mathrm{c}^{\prime}$ show the electrochemical performance of the full coin cell, in which NCM was used as the cathode and $\mathrm{HC}$ or $\mathrm{Si} / \mathrm{C}$ was employed as the anode. Fig. 8a, a' show that whether the anode material is $\mathrm{HC}$ or $\mathrm{Si} / \mathrm{C}$, the initial discharge capacity of the composite electrode NCM + L6C is improved. The initial discharge capacity of the ( $\mathrm{NCM}+\mathrm{L} 6 \mathrm{C})-\mathrm{HC}$ battery is increased by $7.7 \%\left(12.2 \mathrm{~mA} \mathrm{~h}^{-1}\right)$, whereas that of the (NCM + L6C)-Si/C battery is increased by $14.8 \%\left(22.9 \mathrm{~mA} \mathrm{~h} \mathrm{~g}^{-1}\right)$. Besides, as shown in Fig. 8b-c', with $\mathrm{Li}_{6} \mathrm{CoO}_{4}$ addition, the full cell delivers muchimproved rate and cycle performance, which is similar to the full pouch cells due to the low ohmic polarization during cycling (Fig. 7c).

\section{CONCLUSIONS}

Herein, with the view of compensating for the irreversible capacity and increasing the discharge capacity of lithium-ion batteries, a Li-compensation material, $\mathrm{Li}_{6} \mathrm{CoO}_{4}$, was synthesized and investigated. In the first cycle, when $\mathrm{Li}_{6} \mathrm{CoO}_{4}$ was synthesized at $750^{\circ} \mathrm{C}$, a high Li-compensation capacity of $548 \mathrm{~mA} \mathrm{~h} \mathrm{~g}^{-1}$ was obtained, and the charging cutoff voltage was $4.3 \mathrm{~V}$. The chemical states of Co and the structural evaluation were investigated using XPS and ex situ XRD. The influence of $\mathrm{Li}_{6} \mathrm{CoO}_{4}$ on the electrochemical performance of the NCM electrode was also examined. The results show that the capacity retention of the $\mathrm{NCM}+\mathrm{L6C}$ electrode exceeds that of the NCM electrode, which is mainly due to the high conductivity of the reaction products and thus the low ohmic polarization of the electrode during the cycle. The Li-compensation effect of the $\mathrm{Li}_{6} \mathrm{CoO}_{4}$ material was further confirmed using full pouch batteries (3-Ah). The discharge capacity of the (NCM + L6C)-GR full battery was 186.6 $\mathrm{mA} \mathrm{h} \mathrm{g}^{-1}$, which was $6.7 \mathrm{~mA} \mathrm{~h} \mathrm{~g}^{-1}$ higher than that of the pristine battery. After 493 cycles at $1 \mathrm{C}$, the capacity retention of the $(\mathrm{NCM}+\mathrm{L} 6 \mathrm{C})-\mathrm{GR}$ battery was $85.7 \%$, which was substantially higher than that of the NCM-GR battery $(75.3 \%)$. Besides, the rate capabilities of the (NCM + L6C)-GR battery were enhanced, which confirms the low ohmic polarization of the electrode with $\mathrm{Li}_{6} \mathrm{CoO}_{4}$. Furthermore, the $\mathrm{HC}$ and $\mathrm{Si} / \mathrm{C}$ anodes were used to verify the Li-compensation effect of the $\mathrm{Li}_{6} \mathrm{CoO}_{4}$ material, and similar results were obtained. Hence, this study provides an effective strategy for improving the discharge capacity of lithium-ion batteries and their electrochemical performance via the Li-compensating strategy.

Received 22 July 2021; accepted 30 August 2021; published online 30 September 2021

1 Kong L, Liu Y, Huang $\mathrm{H}$, et al. Interconnected $\mathrm{CoS}_{2} / \mathrm{NC}$-CNTs network as high-performance anode materials for lithium-ion batteries. Sci
China Mater, 2021, 64: 820-829

2 Liu Z, Yu Q, Zhao Y, et al. Silicon oxides: A promising family of anode materials for lithium-ion batteries. Chem Soc Rev, 2019, 48: 285-309

3 Wang YY, Gao MY, Liu S, et al. Yttrium surface gradient doping for enhancing structure and thermal stability of high-Ni layered oxide as cathode for Li-ion batteries. ACS Appl Mater Interfaces, 2021, 13: 7343-7354

4 Cao K, Jiao L, Liu $\mathrm{H}$, et al. 3D hierarchical porous $\alpha-\mathrm{Fe}_{2} \mathrm{O}_{3}$ nanosheets for high-performance lithium-ion batteries. Adv Energy Mater, 2015, 5: 1401421

5 Su Z, Liu J, Li M, et al. Defect engineering in titanium-based oxides for electrochemical energy storage devices. Electrochem Energ Rev, 2020, 3: $286-343$

6 Yen HJ, Tsai H, Zhou M, et al. Structurally defined 3D nanographene assemblies via bottom-up chemical synthesis for highly efficient lithium storage. Adv Mater, 2016, 28: 10250-10256

7 Feng Y, Shu N, Xie J, et al. Carbon-coated $\mathrm{Fe}_{2} \mathrm{O}_{3}$ hollow sea urchin nanostructures as high-performance anode materials for lithium-ion battery. Sci China Mater, 2021, 64: 307-317

8 Xin F, Whittingham MS. Challenges and development of tin-based anode with high volumetric capacity for Li-ion batteries. Electrochem Energ Rev, 2020, 3: 643-655

9 Du Z, Zhang S, Liu Y, et al. Facile fabrication of reticular polypyrrolesilicon core-shell nanofibers for high performance lithium storage. J Mater Chem, 2012, 22: 11636-11641

10 Cui LF, Hu L, Choi JW, et al. Light-weight free-standing carbon nanotube-silicon films for anodes of lithium ion batteries. ACS Nano, 2010, 4: 3671-3678

11 Cui LF, Ruffo R, Chan CK, et al. Crystalline-amorphous core-shell silicon nanowires for high capacity and high current battery electrodes. Nano Lett, 2009, 9: 491-495

12 Ren WF, Le JB, Li JT, et al. Improving the electrochemical property of silicon anodes through hydrogen-bonding cross-linked thiourea-based polymeric binders. ACS Appl Mater Interfaces, 2021, 13: 639-649

13 Tan T, Lee PK, Zettsu N, et al. Highly stable lithium-ion battery anode with polyimide coating anchored onto micron-size silicon monoxide via self-assembled monolayer. J Power Sources, 2020, 453: 227874

14 Chen M, Li B, Liu X, et al. Boron-doped porous Si anode materials with high initial coulombic efficiency and long cycling stability. J Mater Chem A, 2018, 6: 3022-3027

$15 \mathrm{Wu}$ W, Wang M, Wang R, et al. Magnesio-mechanochemical reduced $\mathrm{SiO}_{x}$ for high-performance lithium ion batteries. J Power Sources, 2018, 407: $112-122$

16 Chen $\mathrm{T}, \mathrm{Wu}$, Zhang $\mathrm{Q}$, et al. Recent advancement of $\mathrm{SiO}_{x}$ based anodes for lithium-ion batteries. J Power Sources, 2017, 363: 126-144

$17 \mathrm{Xu}$ Q, Sun JK, Yin YX, et al. Facile synthesis of blocky $\mathrm{SiO}_{x} / \mathrm{C}$ with graphite-like structure for high-performance lithium-ion battery anodes. Adv Funct Mater, 2018, 28: 1705235

18 Zhang Y, Mu Z, Lai J, et al. MXene/Si@SiO $@$ @C layer-by-layer superstructure with autoadjustable function for superior stable lithium storage. ACS Nano, 2019, 13: 2167-2175

19 Yang $\mathrm{C}$, Zhang Y, Zhou J, et al. Hollow $\mathrm{Si} / \mathrm{SiO}_{x}$ nanosphere/nitrogendoped carbon superstructure with a double shell and void for high-rate and long-life lithium-ion storage. J Mater Chem A, 2018, 6: 8039-8046

20 Zhuang X, Song $\mathrm{P}$, Chen G, et al. Coralloid-like nanostructured c- $n \mathrm{Si} /$ $\mathrm{SiO}_{x} @ \mathrm{C}_{y}$ anodes for high performance lithium ion battery. ACS Appl Mater Interfaces, 2017, 9: 28464-28472

21 Jiang B, Zeng S, Wang H, et al. Dual core-shell structured Si@SiO $\mathrm{O}_{x} \mathrm{C}$ nanocomposite synthesized via a one-step pyrolysis method as a highly stable anode material for lithium-ion batteries. ACS Appl Mater Interfaces, 2016, 8: 31611-31616

22 Li Y, Fitch B. Effective enhancement of lithium-ion battery performance using SLMP. Electrochem Commun, 2011, 13: 664-667

23 Aravindan V, Lee YS, Madhavi S. Best practices for mitigating irreversible capacity loss of negative electrodes in Li-ion batteries. Adv Energy Mater, 2017, 7: 1602607

24 Forney MW, Ganter MJ, Staub JW, et al. Prelithiation of silicon-carbon nanotube anodes for lithium ion batteries by stabilized lithium metal powder (SLMP). Nano Lett, 2013, 13: 4158-4163 
25 Wang L, Fu Y, Battaglia VS, et al. SBR-PVDF based binder for the application of SLMP in graphite anodes. RSC Adv, 2013, 3: 1502215027

26 Pan Q, Zuo P, Mu T, et al. Improved electrochemical performance of micro-sized SiO-based composite anode by prelithiation of stabilized lithium metal powder. J Power Sources, 2017, 347: 170-177

27 Shellikeri A, Watson VG, Adams DL, et al. Pre-lithiation of carbon anodes using different lithium sources. ECS Trans, 2017, 77: 293-303

28 Zhao H, Wang Z, Lu P, et al. Toward practical application of functional conductive polymer binder for a high-energy lithium-ion battery design. Nano Lett, 2015, 14: 6704-6710

29 Su X, Lin C, Wang X, et al. A new strategy to mitigate the initial capacity loss of lithium ion batteries. J Power Sources, 2016, 324: 150157

30 Zhang L, Dose WM, Vu AD, et al. Mitigating the initial capacity loss and improving the cycling stability of silicon monoxide using $\mathrm{Li}_{5} \mathrm{FeO}_{4}$. J Power Sources, 2018, 400: 549-555

31 Jeżowski P, Fic K, Crosnier O, et al. Lithium rhenium(VII) oxide as a novel material for graphite pre-lithiation in high performance lithiumion capacitors. J Mater Chem A, 2016, 4: 12609-12615

32 Noh $\mathrm{M}$, Cho J. Role of $\mathrm{Li}_{6} \mathrm{CoO}_{4}$ cathode additive in Li-ion cells containing low coulombic efficiency anode material. J Electrochem Soc, 2012, 159: A1329-A1334

33 Guo Y, Li X, Wang Z, et al. Bifunctional $\mathrm{Li}_{6} \mathrm{CoO}_{4}$ serving as prelithiation reagent and pseudocapacitive electrode for lithium ion capacitors. J Energy Chem, 2020, 47: 38-45

34 Liang M, Sun Y, Song D, et al. Superior electrochemical performance of quasi-concentration-gradient $\mathrm{LiNi}_{0.8} \mathrm{Co}_{0.15} \mathrm{Al}_{0.05} \mathrm{O}_{2}$ cathode material synthesized with multi-shell precursor and new aluminum source. Electrochim Acta, 2019, 300: 426-436

$35 \mathrm{Lu} \mathrm{W}$, Yuan Z, Xu C, et al. Construction of mesoporous Cu-doped $\mathrm{Co}_{9} \mathrm{~S}_{8}$ rectangular nanotube arrays for high energy density all-solidstate asymmetric supercapacitors. J Mater Chem A, 2019, 7: 5333-5343

36 Ben Yahia $M$, Vergnet $J$, Saubanère $M$, et al. Unified picture of anionic redox in Li/Na-ion batteries. Nat Mater, 2019, 18: 496-502

37 Li B, Jiang N, Huang W, et al. Thermodynamic activation of charge transfer in anionic redox process for Li-ion batteries. Adv Funct Mater, 2018, 28: 1704864

38 Xiao R, Li H, Chen L. Density functional investigation on $\mathrm{Li}_{2} \mathrm{MnO}_{3}$. Chem Mater, 2012, 24: 4242-4251

39 Xiang X, Knight JC, $\mathrm{Li} \mathrm{W}$, et al. Understanding the effect of $\mathrm{Co}^{3+}$ substitution on the electrochemical properties of lithium-rich layered oxide cathodes for lithium-ion batteries. J Phys Chem C, 2014, 118: 21826-21833

Acknowledgements This work was supported by the National Key R\&D Program of China (2016YFB0100500) and the Young Elite Scientists Sponsorship Program by Tianjin (TJSQNTJ-2017-05).

Author contributions Zhang $\mathrm{H}$ conceived the idea and designed the experiments. $\mathrm{Na} \mathrm{Z}$ designed and carried out the experiments and wrote the paper. Lai C, Song D, and Shi X analyzed the data and refined the manuscript. Zhang L and Zhou J supervised the project. All authors contributed to the general discussion.

Conflict of interest The authors declare that they have no conflict of interest.

Supplementary information Supporting data are available in the online version of the paper.

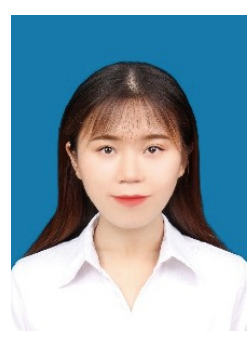

Ziyu Na received her bachelor's degree in 2018. She joined the School of Materials Science and Engineering, Tianjin University of Technology, in 2021. Her current research interests are mainly focused on the Li-compensation material for lithium-ion batteries.

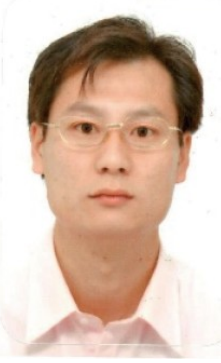

Hongzhou Zhang obtained his $\mathrm{PhD}$ degree in $\mathrm{Ma}$ terials Science from Nankai University (China) in 2015. Then, he joined Prof. Lianqi Zhang's group at Tianjin University of Technology, China. His current research focused on functional materials and their application in energy conversion and storage devices.

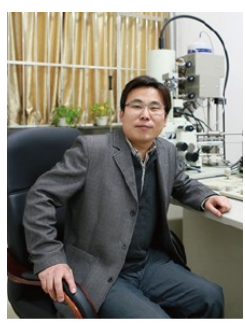

Lianqi Zhang is a professor at Tianjin University of Technology, China. He obtained his $\mathrm{PhD}$ degree in chemistry from Soga University (Japan) in 2003. His current interest is focused on the applied research in lithium-ion batteries, the structure, and the electrochemical properties of new materials for energy storage and conversion.

\section{补锂材料 $\mathrm{Li}_{6} \mathrm{CoO}_{4}$ 提高锂离子电池容量和循环性能}

那子玉 ${ }^{1}$, 赖超 ${ }^{2}$, 周江 $^{3}$, 张洪周 ${ }^{1 *}$, 宋大卫 ${ }^{1}$, 时喜喜 ${ }^{1}, 弓^{2}$ 联齐 $^{1^{*}}$

摘要 $\mathrm{SiO}$ 和 $\mathrm{Si} / \mathrm{C}$ 具有高容量, 被认为是高能量密度锂离子电池有前景 的负极材料. 然而, 副反应(形成 $\mathrm{Li}_{2} \mathrm{O}$ 和硅酸锂) 和固体电解质界面( $\mathrm{SEI}$ ) 膜的形成, 导致这些负极材料初始库仑效率、活性锂离子数量以及放 电容量的降低. 在正极或负极中添加补锂材料是解决这一问题的有效 方法. 最常用的补锂材料是稳定锂金属粉末(SLMP), 但这种策略存在 安全风险高、成本高且难以实现定量补理的缺点. 本文合成并研究了 $\mathrm{Li}_{6} \mathrm{CoO}_{4}$ 锂补偿材料, 分析和讨论了其制备条件、空气中的稳定性、脱 锂机制和结构转变机理. 研究结果表明, 添加 $\mathrm{Li}_{6} \mathrm{CoO}_{4}$ 能在发挥补锂作 用的同时, 显著提高软包全电池(3-Ah)的循环性能. 这项工作提供了一 种有效的补锂策略, 是提高锂离子电池电化学性能的有效方法. 